\title{
Antibody responses to recombinant and plasma derived hepatitis B vaccines
}

\author{
SHEILA E BROWN, CAROLYNNE STANLEY, \\ MICHAEL W STEWARD \\ COLIN R HOWARD, ARIE J ZUCKERMAN,
}

\section{Abstract}

The antibody response to hepatitis B surface antigen (anti-HBs) induced in 25 recipients of a recombinant hepatitis $B$ vaccine derived from yeast was compared with that induced in 25 recipients of a vaccine prepared from hepatitis $B$ surface antigen (HBsAg) derived from plasma. Anti-HBs affinity and specificity were compared using assays of antibody affinity with two different antigens, a complex of the major polypeptide of $\mathrm{HBsAg}$ (p25; molecular weight $\mathbf{2 5 0 0 0}$ daltons) covalently linked to its glycosylated form (gp30) prepared from native purified $\mathrm{HBsAg}$, and a cyclical synthetic peptide representing amino acid residues 139-147 of the major polypeptide of $\mathrm{HBsAg}$ and known to represent a major part of an $a$ determinant. There was no difference in anti-HBs affinity or molar antigen binding sites of the antibody measured with either antigen between the two groups. All subjects in both groups produced antibody that bound to the gp30/p25 complex antigen, whereas 22 of the recipients of the plasma derived vaccine compared with 24 of those receiving the yeast derived vaccine produced antibodies that bound to the cyclical synthetic peptide 139-147. These results support the finding of similar levels of anti-HBs, measured by commercial solid phase radioimmunoassay, in the two vaccine groups after three doses of vaccine.

These results show no significant difference in the quantity, quality, or specificity of the anti-HBs response induced by the recombinant hepatitis $B$ vaccine and the plasma derived hepatitis $B$ vaccine.

\section{Introduction}

The most important immunological response to hepatitis $B$ virus is directed towards antigenic determinants on the surface of the virus particle, hepatitis B surface antigen ( $\mathrm{HBsAg})$. Antibody to $\mathrm{HBs} \mathrm{Ag}$ (anti-HBs) is known to protect against reinfection ${ }^{1}$ with any $\mathrm{HBsAg}$ subtype if the antibody is directed towards the group specific $a$ determinant present on all subtype variants of $\mathrm{HBsAg} .{ }^{23}$ This has led to the development of a hepatitis $B$ vaccine, which consists of highly purified and inactivated $\mathrm{HBsAg}$ particles isolated from the plasma of persistently infected subjects. ${ }^{4}$ The safety and efficacy of this vaccine in various population groups at risk of acquiring hepatitis B has been established. ${ }^{12}$ The current vaccine, separated from the plasma of asymptomatic carriers, is, however, expensive and requires extensive purification and inactivation by at least two different procedures and vigorous safety testing to ensure freedom from host proteins and contaminating transmissible agents. Moreover, production of antibodies, assessed by radioimmunoassay, is poor in patients receiving maintenance haemodialysis ${ }^{56}$ and immunocompromised patients. ${ }^{78}$ There is, therefore, a need to develop safe and effective vaccines from alternative sources of HBsAg.

In the absence of a cell culture for propagating hepatitis B virus, recombinant deoxyribonucleic acid (DNA) methods provide a good alternative for the production of $\mathrm{HBsAg}$ for immunisation purposes. Cloning of the hepatitis $\mathrm{B}$ virus genome and determination of its primary sequence have identified a continuous 892 base pair sequence, which constitutes the gene coding for $\mathrm{HBsAg}$ (the $\mathrm{S}$ gene). ${ }^{9.11}$ The cloned $S$ gene has been introduced into yeast (Saccharomyces cerevisiae), and the expressed HBsAg was shown to elicit specific anti-HBs antibodies in mice, rabbits, chimpanzees, and humans. ${ }^{322-18}$

We have previously shown the importance of determining the affinity of the anti-HBs response using synthetic peptides representing the amino acid sequence of part of an $a$ determinant of HBsAg. ${ }^{192}$ The quantitative commercial antibody assays are inadequate because they provide no information on the epitope specificity and quality of the antibody response. In this context it should be noted that several antibody assays, particularly the enzyme linked immunosorbent assay, are more sensitive to high affinity antibodies than low. ${ }^{21}{ }^{22}$ We compared the amount, affinity, and specificity of the anti-HBs responses in subjects who had

\footnotetext{
Department of Medical Microbiology, London School of Hygiene and Tropical Medicine, London WC1E 7HT

SHEILA E BROWN, PHD, BSC, research fellow

COLIN R HOWARD, MRCPATH, DSC, reader in virology

ARIE J ZUCKERMAN, FRCP, FRCPATH, professor of microbiology

MICHAEL W STEWARD, FRCPATH, DSC, professor of immunology

Correspondence to: Dr Brown.
} 
received the current vaccine containing HBsAg isolated from plasma of persistently infected donors and in those who had received a vaccine containing $\mathrm{HBs} A g$ produced by the recombinant DNA method in yeast.

\section{Methods}

Serum samples were obtained from 50 volunteers who had received three doses of hepatitis $B$ vaccine. Of these, 25 had received vaccine prepared by Merck Sharp and Dohme research laboratories from $\mathrm{HBsAg}$ expressed in yeast by the Merck process ${ }^{3}$ and the remaining 25 had received vaccine prepared from human plasma positive for $\mathrm{HBsAg}$ (Hep-B Vax, Merck Sharp and Dohme). Both sets of subjects belonged to similar age and risk groups and were treated with identical regimens of vaccine. All serum samples were taken at seven months, one month after the third dose of vaccine. Serum titres of anti-HBs were measured by solid phase radioimmunoassay (Ausab, Abbott Laboratories, Chicago).

Affinities of antibodies to $\mathrm{HBsAg}$ in the serum were determined as described previously, using two different antigens labelled with iodine125. 1920 The first was a Triton X-100 solubilised complex (gp30/p25) of the major $\mathrm{HBsAg}$ polypeptide, $\mathrm{p} 25$, with its glycosylated form, $\mathrm{gp} 30$, prepared from purified $22 \mathrm{~nm}$ HBsAg particles, ${ }^{23}$ and the second was a cyclical synthetic peptide representing amino acid residues 139 to 147 of the major polypeptide of HBsAg and known to represent part of a group specific $a$ determinant of HBsAg present on all subtype variants. ${ }^{192425}$

\section{Results and comment}

The figure shows the affinity values and the molar antigen binding sites of the antibody (Abt values) obtained with the serum samples from both groups, using as antigens either the gp $30 / \mathrm{p} 25$ complex or the cyclical synthetic peptide 139-147. There was significant correlation of the Abt values between the two antigens (yeast vaccine $r=0 \cdot 6129$, plasma vaccine $\mathrm{r}=0.8904 ; \mathrm{p}<0.01$ ). There was no significant correlation, however, between the antibody affinity values using the gp $30 / \mathrm{p} 25$ complex and the cyclical peptide (yeast vaccine $r=0 \cdot 2407$, plasma vaccine $r=0 \cdot 0404 ; p>0 \cdot 1$ ). Serum samples from all 50 subjects yielded positive results on solid phase radioimmunoassay for anti-HBs, and all contained detectable antibody that bound to the gp $30 / \mathrm{p} 25$ complex. However, three subjects in the group who
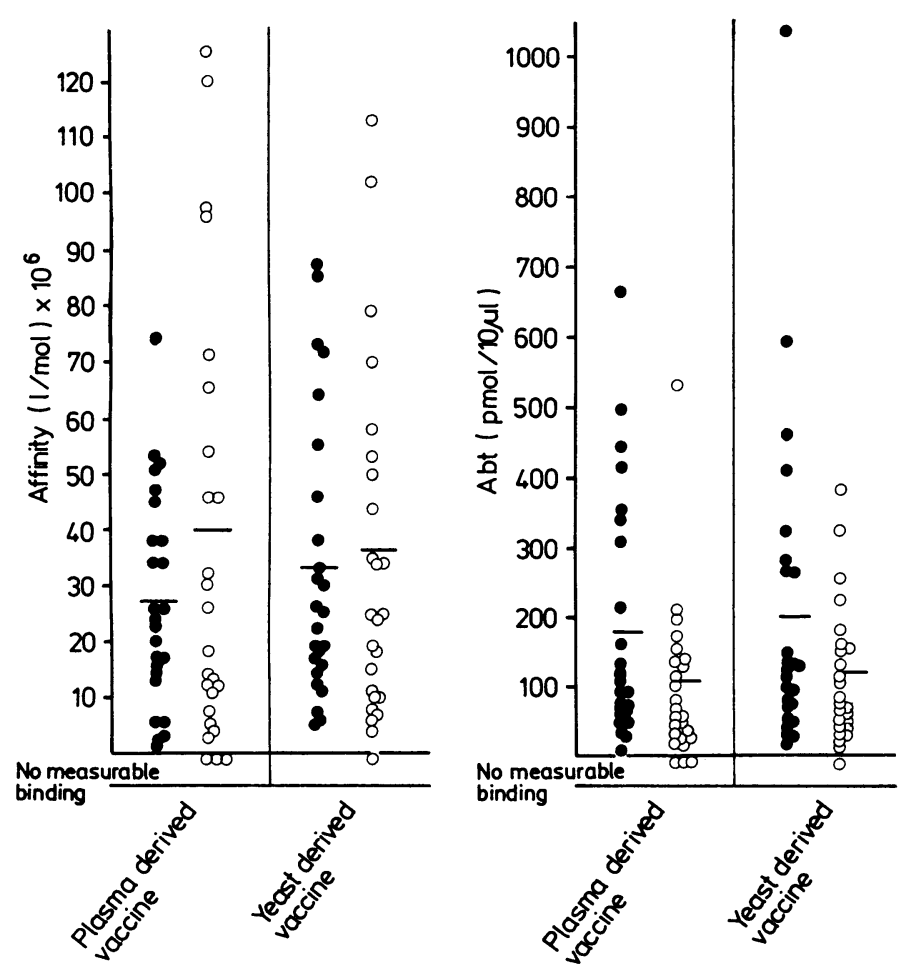

Affinity values and Abt values (molar antigen binding sites of the antibody) of anti-HBs antibodies in recipients of three doses of plasma derived hepatitis B vaccine and yeast derived hepatitis $B$ vaccine measured with gp $30 / \mathrm{p} 25$ complex (O) and cyclical synthetic peptide 139-147(○). Mean values are indicated by bars. had received vaccine made from $\mathrm{HBsAg}$ isolated from human plasma and one subject in the group who had received yeast derived $\mathrm{HBsAg}$ vaccine had no detectable antibody specific for the cyclical synthetic peptide 139-147.

The mean affinity values and mean Abt values for antibodies to both antigens and the mean titres for the two groups were not significantly different (Student's $t$ test, $\mathrm{p}>0 \cdot 3$ ). Jilg et al reported slightly lower seroconversion rates and mean anti-HBs levels, particularly in male patients, in recipients of a recombinant vaccine compared with those vaccinated with a plasma derived vaccine. ${ }^{14}$ They suggested that this may have been because of the lower dose of recombinant vaccine used $(10 \mu \mathrm{g})$ compared with the dose of plasma derived vaccine $(20 \mu \mathrm{g})$. Our data confirm the preliminary results reported by two other groups, showing similar seroconversion rates and anti-HBs titres with both recombinant and plasma derived vaccines..$^{15} 16$

To assess the anti-HBs responses in the two groups more fully specificity and quality of the anti-HBs were measured using the gp $30 / \mathrm{p} 25$ complex and the cyclical synthetic peptide 139-147. The gp 30/p25 complex is derived from native purified HBsAg and is considered to bear the major antigenic determinants of the native protein. ${ }^{26} 27$ In contrast, synthetic peptide 139-147 corresponds to a major part of an $a$ group determinant of $\mathrm{HBsAg} .{ }^{192425} \mathrm{Al}$ subjects in both groups produced antibodies that bound to the gp $30 / \mathrm{p} 25$ complex. In addition, 24 of the 25 subjects who had received yeast derived vaccine and 22 of the 25 who had received the plasma derived vaccine produced antibodies that bound to the synthetic peptide 139-147. This does not necessarily mean that the four subjects who did not have antibody that bound synthetic peptide 139-147 did not have antibody directed to part of the $a$ determinants, because peptide 139-147 does not represent all of the $a$ determinants. In the study of Jilg $e t$ al all subjects who seroconverted had antibodies against the $a$ determinants in both the recombinant and plasma derived groups. ${ }^{14}$

\section{Discussion}

We found no significant difference in the affinity of the anti-HBs that bound to the gp $30 / \mathrm{p} 25$ or the cyclical synthetic peptide $139-147$ between the two groups. The cyclical form of peptide 139-147 was used in preference to a linear form as we have previously shown that anti-HBs serum samples always bind to the cyclical form of the peptide with a higher affinity. ${ }^{1920}$ The cyclical form therefore probably corresponds more closely than the linear form of the peptide to the conformation of this amino acid sequence in the native $\mathrm{HBsAg}$. In this context it should be recognised that peptide conformation is important for interaction with antibodies raised against native $\mathrm{HBsAg} .{ }^{28}$ The affinity values of anti-HBs induced in both the recombinant and plasma derived vaccine groups reported here are similar to those previously reported in a group of 19 subjects who received the currently licensed plasma derived vaccine..$^{20}$ The affinity of anti-HBs in these subjects for the cyclical synthetic peptide 139-147 was shown to be similar to the high affinity of anti-HBs antibody in a group of 13 patients who had recovered from acute hepatitis B. ${ }^{19}$ There is considerable evidence to suggest that antibody affinity influences the biological properties of antisera, ${ }^{29}$ and, in particular, high affinity antibody has been shown to be superior to low affinity antibody in several functions mediated by antibodies such as immune elimination of antigen, virus neutralisation, and, in man, the prevention of $\mathrm{Rh}$ immunisation by the use of passively transferred anti-D antibodies..$^{30-32}$

Our results show that the yeast recombinant $\mathrm{HBsAg}$ vaccine induced the production of high affinity anti-HBs in man. The affinity, titre, and specificity of this antibody response were similar to those obtained after immunisation with the plasma derived HBsAg vaccine.

The hepatitis B vaccine development programme at the London School of Hygiene and Tropical Medicine is supported by the Department of Health and Social Security, the British Technology Group, the Wellcome Trust, the European Economic Commission, and the Christopher Kimber bequest. We thank Dr William J McAleer of Merck Sharp and Dohme Research Laboratories for providing the serum samples from vaccinees and the results of the Ausab assays.

\section{References}

1 Szmuness W, Stevens CE, Harley EJ, et al. Hepatitis B vaccine: demonstration of efficacy in a controlled clinical trial in a high-risk population in the United States. $N$ Engl $\mathcal{f}$ Med 1980;303:833-41. 
BRITISH MEDICAL JOURNAL VOLUME 29218 JANUARY 1986

2 Szmuness $\mathrm{W}$, Stevens CE, Harley EJ, et al. Hepatitis B vaccine in medical staff of hemodialysis units: efficacy and subtype cross-protection. $N$ Englf $\mathrm{Med}$ 1982;307:1481-6.

3 McAleer WJ, Buynak EB, Maigetter RZ, Wampler DE, Miller WJ, Hilleman MR. Human hepatitis B vaccine from recombinant yeast. Nature 1984;307:178-80.

4 Hilleman MR, McAleer WJ, Buynak EB, McLean AA. Quality and safety of human hepatitis B vaccine. Dev Biol Stand 1983;54:3-12.

5 Stevens CE, Szmuness W, Goodman AI, Weseley SA, Fortino M. Hepatitis B vaccine: immune responses in haemodialysis patients. Lancet 1980;ii:1211-3.
rentions

6 Anonymous. Hepatitis B vaccine and haemodialysis [Editorial]. Lancet 1984;ii:962-3.

7 Feuerhake A, Muller R, Lauchart W, Pichlmayr R, Schmidt FW. HBV-vaccination in recipients of kidney allografts. Vaccine 1984;2:255-6.

8 Stevens CE, Alter HJ, Taylor PE, Zang EA, Harley EJ, Szmuness W. Hepatitis B vaccine in patients receiving hemodialysis: immunogenicity and efficacy. $N$ Engl f Med 1984;311: 496-501.

9 Galibert F, Mandart E, Fitoussi F, Tiollais P, Charnay P. Nucleotide sequence of the hepatitis B virus genome (subtype ayw) cloned in E coli. Nature 1979;281:646-50.

10 Pasak M, Gato F, Gilbert W, et al. Hepatitis B virus genes and their expression in E coli. Nature 1979;282:575-9.

11 Valenzuela P, Gray P, Quiroga M, Zaldivar J, Goodman HM, Rutter WE. Nucleotide sequence of the gene coding for the major protein of hepatitis B surface antigen. Nature 1979;280:815-9.

12 Valenzuela P, Medina A, Rutter WJ, Ammerer G, Hall BD. Synthesis and assembly of hepatitis B virus surface antigen particles in yeast. Nature 1982;298:347-50.

13 Harford N, Cabezon T, Crabeel M, Simden E, Rutgens A, DeWilde M. Expression of hepatitis B surface antigen in yeast. Dev Biol Stand 1983;54:125-30

14 Jilg W, Schmidt M, Zoulek G, Lorbeer B, Wilske B, Deinhardt F. Clinical evaluation of a recombinant hepatitis B vaccine. Lancet 1984;ii:1174-5.

15 Davidson $M$, Krugman S. Immunogenicity of recombinant yeast hepatitis B vaccine. Lancet 1985 ; : $108-9$

16 Papaevangelou G, Dandolos E, Roumeliotou-Karayannis A, Richardson SC. Immunogenicity of recombinant hepatitis B vaccine. Lancet 1985 ; ; $4555-6$.

17 Scolinck EM, McLean AA, West DJ, McAleer WJ, Miller WJ, Buynak EB. Clinical evaluation in healthy adults of a hepatitis B vaccine made by recombinant DNA. FAMA 1984;251:2812-5.

18 Dandolos E, Roumeliotou-Karavannis A, Richardson SC, Papaevangelou G. Safety and immunogenicity of a recombinant hepatitis B vaccine. $\mathcal{F} \mathrm{Med}$ Virol (in press).
19 Brown SE, Howard CR, Zuckerman AJ, Steward MW. Determination of the affinity of antibodies to hepatitis B surface antigen in human sera. 7 Immunol Methods 1984;72:41-8.

20 Brown SE, Howard CR, Zuckerman AJ, Steward MW. Affinity of antibody responses in man to hepatitis B vaccine determined with synthetic peptides. Lancet 1984:ii:184-7.

21 Lew AM. The effect of epitope density and antibody affinity on the ELISA as analysed by monoclonal antibodies. F Immunol Methods 1984;72:171-6.

22 Nimmo GR, Lew AM, Stanley CM, Steward MW. Influence of antibody affinity on the performance of different antibody assays. 7 Immunol Methods 1984;72:177-87.

23 Young P, Vaudin M, Dixon J, Zuckerman AJ. Preparation of hepatitis B polypeptide micelles from human carrier plasma. $\mathcal{G}$ Virol Methods 1982;4:177-85.

24 Bhatnager PK, Papas E, Blum HE, et al. Immune response to synthetic peptide analogues of hepatitis B. surface antigen specific for the a determinant. Proc Natl Acad Sci USA 1982;79:4400-4.

25 Prince AM, Ikram H, Hopp TP. Hepatitis B virus vaccine: identification of $\mathrm{HBsAg} / \mathrm{a}$ and $\mathrm{HBsAg} / \mathrm{d}$ but not $\mathrm{HBsAg} / \mathrm{y}$ subtype antigenic determinants on a synthetic immunogenic peptide. Proc Natl Acad Sci USA 1982;79:579-82.

26 Peterson DL. Isolation and characterization of the major protein and glycoprotein of hepatitis B surface antigen. F Biol Chem 1981;256:6975-83.

27 Shih JWK, Gerin JL. Proteins of hepatitis B surface antigen. Amino acid composition of the major polypeptides. 7 Virol 1977:21:1219-22.

28 Ionescu-Matiu I, Kennedy RC, Sparrow JT, et al. Epitopes associated with a synthetic hepatitis B surface antigen peptide. $\mathcal{F}$ Immunol 1983;130:1947-52.

29 Steward MW, Steensgaard J. Antibody affinity: thermodynamic aspects and biological significance. Boca Raton, Florida: CRC Press, 1983.

30 Alpers JH, Steward MW, Soothill JF. Differences in immune elimination in inbred mice. The role of low affinity antibody. Clin Exp Immunol 1972;12:121-32.

31 Blank SE, Leslie GA, Clem LW. Antibody affinity and valence in viral neutralization. $f$ I mmunol 1972;108:665-73.

32 Hughes-Jones NC. The estimation of the concentration and equilibrium constant of anti-D. Immunology 1967;12:565-71

\title{
Lactose absorption, milk consumption, and fasting blood glucose concentrations in women with idiopathic osteoporosis
}

\author{
G FINKENSTEDT，F SKRABAL， R W GASSER， H BRAUNSTEINER
}

\begin{abstract}
Lactose tolerance tests were performed in 33 women with osteoporosis and 33 control women matched for age. A questionnaire was used to elicit any history of milk intolerance and the subjects' daily intake of calcium derived from milk and dairy products. Eleven patients and four controls gave a history of milk intolerance $(p<0.01) ; 13$ patients had lactose malabsorption compared with four controls $(p<0.01)$. The daily intake of calcium derived from milk was significantly lower in patients $(125$ (SEM 20) mg v 252 (43) mg; $p<0.05$ ). Curves of blood glucose concentrations during the lactose tolerance test in subjects with lactose malabsorption were significantly flatter in patients than controls $(p<0.05)$. The fasting blood glucose concentration was higher $(5.44(0.17) \mathrm{mmol} / \mathrm{l}(98(3) \mathrm{mg} / 100 \mathrm{ml}))$ in the patients than the controls $(4.88(0.11) \mathrm{mmol} / 1(88(2) \mathrm{mg} / 100 \mathrm{ml}) ; \mathrm{p}<0.05)$, although body weight was significantly lower $(61 \cdot 6(2 \cdot 2) \mathrm{kg} v 66.3$ $(1.6) \mathrm{kg} ; \mathrm{p}<0.05)$.
\end{abstract}

Absorption of lactose is significantly impaired in women with "idiopathic" osteoporosis; this combined with low consumption

\footnotetext{
Department of Internal Medicine, University Hospital, University of Innsbruck, 6020 Innsbruck, Austria

G FINKENSTEDT, MD, senior registrar

F SKRABAL, MD, professor, chief of division of endocrinology and hypertension

R W GASSER, MD, senior registrar

$\mathrm{H}$ BRAUNSTEINER, MD, professor of internal medicine and head of department

Correspondence to: Dr Finkenstedt.
}

of milk and a subclinical disorder of glucose metabolism may be a major factor in the development of idiopathic osteoporosis in women.

\section{Introduction}

The contribution of malabsorption of lactose to the development of osteoporosis is not well documented. Birge et al and Newcomer et al found an increased incidence of lactose intolerance in patients with osteoporosis, ${ }^{12}$ while Alhava et al could not show any difference in bone mineral content between subjects with and without lactose intolerance. ${ }^{3}$ We determined the prevalence of lactose malabsorption and the amount of calcium consumed that was derived from milk and dairy products in 33 women with osteoporosis compared with 33 control women matched for age.

\section{Patients, methods, and results}

Thirty three women aged under 65 with "idiopathic" osteoporosis were compared with 33 women without osteoporosis (Singh index $>4$ ) of the same ethnic origin matched for age. We excluded patients with endocrine disorders, liver and renal disease, postgastrectomy states, malabsorption syndromes, rheumatoid arthritis, osteomalacia, and malignancy and patients receiving corticosteroids. Patients and controls were not taking drugs that influenced calcium or bone metabolism. Osteoporosis was confirmed by the presence of reduced bone mineral density in plain $x$ ray films and either a femoral trabecular index $<5^{4}$ or the presence of spontaneous fractures of vertebrae or long bones, or both.

Malabsorption of lactose was defined as a rise in glucose concentration of $<1.11 \mathrm{mmol} / \mathrm{l}(20 \mathrm{mg} / 100 \mathrm{ml})$ in capillary blood samples taken at 30 minute intervals after the ingestion of $50 \mathrm{~g}$ lactose dissolved in water. ${ }^{5}$ Patients were given a questionnaire asking about their mean daily or weekly ingestion of milk, yoghourt, cottage cheese, and other cheese and about tolerance to 